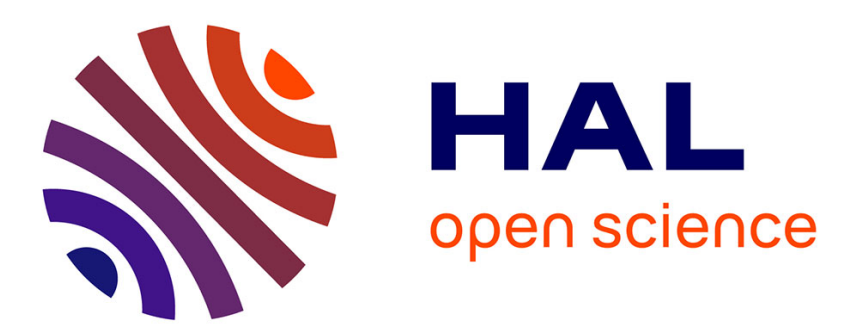

\title{
The role of developmental stage in frost tolerance of Pinus pinea L. seedlings and saplings
}

\author{
Marta Pardos, José Climent, Helena Almeida, Rafael Calama
}

\section{To cite this version:}

Marta Pardos, José Climent, Helena Almeida, Rafael Calama. The role of developmental stage in frost tolerance of Pinus pinea L. seedlings and saplings. Annals of Forest Science, 2014, 71 (5), pp.551-562. 10.1007/s13595-014-0361-9 . hal-01102304

\section{HAL Id: hal-01102304 \\ https://hal.science/hal-01102304}

Submitted on 12 Jan 2015

HAL is a multi-disciplinary open access archive for the deposit and dissemination of scientific research documents, whether they are published or not. The documents may come from teaching and research institutions in France or abroad, or from public or private research centers.
L'archive ouverte pluridisciplinaire HAL, est destinée au dépôt et à la diffusion de documents scientifiques de niveau recherche, publiés ou non, émanant des établissements d'enseignement et de recherche français ou étrangers, des laboratoires publics ou privés. 


\title{
The role of developmental stage in frost tolerance of Pinus pinea $\mathrm{L}$. seedlings and saplings
}

\author{
Marta Pardos • José Climent • Helena Almeida • \\ Rafael Calama
}

Received: 9 September 2013 / Accepted: 13 January 2014 /Published online: 14 February 2014

(C) INRA and Springer-Verlag France 2014

\begin{abstract}
- Context Although drought is generally considered the main environmental constraint in Mediterranean environments, the ability to acclimate to and tolerate frost in early developmental stages can be a determinant for seedling survival of many Mediterranean tree species like stone pine (Pinus pinea L.).

- Aims The aim of this study was to assess the impact of the developmental stage of naturally regenerated stone pine individuals on tolerance to low temperature (LT) from summer to late autumn and in spring, at a highly continental site in central Spain. Specifically, we tested to what extent the differences in tolerance are related to shoot heteroblasty.

- Methods We assessed LT tolerance of needles from individuals at three age classes (class $\mathrm{C} 1$ : seedlings, class $\mathrm{C} 2$ : 4- to 8year-old saplings and class $\mathrm{C} 3$ : $>9$-year-old saplings) over nine dates from summer to spring.

- Results LT tolerance displayed severe seasonal trends and differed between age classes. It usually increased with sapling age. Such differences were tightly related to heteroblasty of the shoots. Our results point to a higher LT tolerance
\end{abstract}

Handling Editor: Gilbert Aussenac

Contribution of the co-authors The first and last authors developed the idea of the study, set up the experimental design and conducted the experimental part of the study. Both authors have been jointly working in the ecology of stone pine natural regeneration since long. The first author wrote the main body of the text. The last author did the statistical analysis and modelling. The second and third authors contributed to improve the text with their own experience in freezing injury. The second author also contributed with his knowledge in ontogeny differentiation and heteroblasty of pines that help greatly to discuss our results.

M. Pardos $(\bowtie) \cdot$ J. Climent $\cdot$ R. Calama

Department of Sylviculture and Forest System Management, CIFOR-INIA, crtra Coruña Km 7.5, 28040 Madrid, Spain

e-mail: pardos@inia.es

H. Almeida

ISA, Tapada de Ajuda, 1349-017 Lisbon, Portugal associated with larger leaf dry mass per unit area (LMA) values. No impact of late frosts on shoot growth rates was detected during this study.

- Conclusions Developmental changes during early plant growth seem to play a role in frost tolerance of stone pine seedlings, a finding which furthers our understanding of regeneration dynamics in this species in areas with continental influence.

Keywords Mediterranean stone pine · Low-temperature acclimation $\cdot$ Electrolyte leakage $\cdot$ Phase change $\cdot$ Late spring frosts

\section{Introduction}

The timing of growth, cessation, dormancy, cold acclimation, subsequent deacclimation and depth of cold hardiness are critical components of survival for plants in temperate climates (e.g. Kalcsits et al. 2009). The alterations induced by low temperatures comprise changes in the concentrations of a wide range of metabolites (sugars, protective proteins), modification of cell membranes, changes in hormone levels and alterations in gene expression (Costa e Silva et al. 2009). Despite the fact that low-temperature (LT) tolerance in conifers (also referred to as cold or frost tolerance or hardiness or frost sensitivity) has been investigated for over a century in temperate (e.g. Bigras et al. 2001) and boreal (e.g. Strimbeck et al. 2008) species, relatively little is known about the mechanisms associated with LT tolerance in natural regeneration of Mediterranean continental pine species (e.g. Sakai 1983; Climent et al. 2009).

Although drought is widely considered the main environmental constraint in Mediterranean ecosystems, LT tolerance plays a decisive role in inland and mountain areas where frosts can be equally or more limiting than drought (Puértolas et al. 
2005; Thomas and Sporns 2009). Drought and frost, for instance, lead to similar physiological responses in conifers, which are aimed at preventing cellular dehydration (Costa e Silva et al. 2009). Spring LT tolerance is an adaptive trait of considerable importance in Mediterranean ecosystems. Injury by spring frost events can occur prior to bud burst, as tissues deacclimate in the spring, or after bud burst, as a damage to newly flushed shoots (e.g. Larcher 2005). Even at the same phase of bud break, spring LT tolerance can differ depending on the hardening conditions during the previous autumn (Hannertz 1994). Thus, hardening conditions in autumn may influence seedling susceptibility to frost during dehardening and shoot elongation (Sogaard et al. 2009).

The effects of global warming can be complex and counterintuitive in mountain or inland Mediterranean ecosystems. More frequent drought events may make up for diminished acclimation due to warming (Kreyling et al. 2013). The rise in mean autumn and winter temperatures, the changes in the timing of the onset of subfreezing temperatures or in the frequency and duration of midwinter thaws and the unpredictability of spring frost events could lead to inadequate responses in some species (Palacio et al. 2005). In spite of the rise in temperatures during autumn and winter, plants may be more prone to freezing injury due to wide temperature fluctuations (Kalcsits et al. 2009). Thus, the lack of plant synchrony with the environment could be a primary cause of temperature stress injury, and only proper timing of hardening in autumn and dehardening in spring will minimize frost damage (Ensminger et al. 2009).

Given that the first years are critical for the establishment of pine natural regeneration, differential responses to extreme temperatures in early developmental stages are likely to be subjected to strong directional selection within the species' ecological niche (Climent et al. 2009). Furthermore, the different susceptibility to frosts of tree seedlings is frequently related to differences in the developmental features of juvenile and adult plants (Darrow et al. 2001; Winn 1999; Gusta et al. 2009). Heteroblasty is defined as a rather sudden and substantial change in the form of plant structures during ontogeny, as opposed to the more gradual or subtle ontogenetic changes occurring in all species (Zotz et al. 2011). In the case of pines particularly, the change from juvenile shoot with solely primary needles to an adult shoot with secondary needles bundled in fascicles implies marked physiological differences (Zotz et al. 2011). In pines, the primary needles are generally more sensitive to frost damage than the secondary needles (Climent et al. 2009). At least part of these ontogenetic differences in LT tolerance between juvenile and adult foliage may be due to the generally higher sclerophylly of adult leaves in many species. Since leaf dry mass per unit area (LMA) is often used to quantify leaf structure (i.e. thicker or denser leaves mean higher LMA), differences in leaf mass per area are a simple proxy of variable leaf sclerophylly in plants (Han et al. 2008). As lignified or suberized tissues present in sclerophyllous leaves offer physical barriers to the propagation of ice within leaf tissues (Larcher 2005), a high leaf mass per area can partly explain higher LT tolerance within a given species.

In addition to changes in ontogenetic development, LT tolerance in Mediterranean woody plants and particularly acclimation processes are closely linked to the seasonal developmental phases, i.e. phenology (e.g. Palacio et al. 2005), although the interplay between phenology and ontogenetic heteroblasty in young plants remains largely unexplored (Jones 1999). Plants need to finish their growth before starting cold acclimation. However, many Mediterranean species show sequential phenological patterns (Castro-Díez and Montserrat-Martí 1998) and physiological activity (Pardos et al. 2010) throughout most of the year.

The Mediterranean stone pine or umbrella pine (Pinus pinea) is one of the most characteristic trees of the Mediterranean flora. Although this species is well adapted to the coastal thermo-Mediterranean areas where frost damage is not a relevant issue, it also thrives naturally in sandy continental areas of central Spain, where yearly and daily thermal oscillations are huge and night frosts are frequent for several months of the year. Like other temperate pines, adult stone pine shoots have a cyclic, preformed growth pattern (Lanner 1976) occurring mainly in spring, from April to late Juneearly July. By contrast, young seedlings show neo-formed growth with exclusively primary needles for several years, and shoot growth merely stops in autumn with a typical brushlike apex, instead of a true winter bud (Mutke et al. 2012). The growth rate is slow in early spring and reaches a maximum close to the end of the elongation period. The combination of unusually warm early springs which advance shoot phenology by several weeks and the occurrence of only one night frost in May can damage the soft tissues of some shoots (Mutke et al. 2003, Mutke et al. 2005). True winter buds may not be present until 4 to 8 years of age depending on environmental conditions. This ontogenetic delay linked to shoot heteroblasty is shared by other Mediterranean pine species, like Pinus halepensis and Pinus canariensis (Climent et al. 2011; Klaus 1989).

In this study we evaluate the mechanisms of LT acclimation and LT tolerance in needles from three classes of naturally regenerated individuals of stone pine ( $P$. pinea $\mathrm{L}$.) at a highly continental site in central Spain. Although buds are usually hardier than needles (Burr et al. 1990), we used needles in our study precisely because younger stone pines do not have welldefined winter buds or a clear budburst (Mutke et al. 2003). Several studies have been conducted in recent years to detect possible bottlenecks in the different stages of natural regeneration in stone pine: cone production (Calama et al. 2008, 2011), seed dispersal (Manso et al. 2012), seed germination (Manso et al. 2013) or seed predation (Manso et al. 2014). In 
the present study, we address the question of whether the developmental changes during early plant stages hold the key to a clearer understanding of stone pine regeneration dynamics associated with frost acclimation.

Our main objective was to determine the influence of the developmental status of stone pine seedlings in LT tolerance from summer through late autumn and in spring. Most studies have concentrated on cold hardiness in the fall, just before elongation stops, and in the spring just after elongation resumes. These are the periods when frost damage poses the greatest risk to temperate conifers (Bower and Aitken 2006). Specifically, we ask whether the differences in LT tolerance between age classes are related to differences in shoot heteroblasty. We use LMA as an indicator of the ontogenetic differences in LT tolerance between juvenile and adult foliage, although other potential drivers (e.g. carbohydrates) that could be influential were not included in the analysis.

\section{Materials and methods}

\subsection{Study site, sampling and sample preparation}

This study site was located in central Spain $\left(41^{\circ} 28^{\prime} \mathrm{N}, 4^{\circ} 43^{\prime}\right.$ $\mathrm{W})$, at an altitude of $710 \mathrm{~m}$ in a natural even-aged (100120 years old) $P$. pinea stand. Soils are deep sandy deposits typical of the flat sedimentary area of the Duero river basin. The climate is moderately dry and continental, with an average annual rainfall of $450 \mathrm{~mm}$, large day-night temperature oscillation, monthly mean temperatures ranging from $4.0^{\circ} \mathrm{C}$ in January to $21.7^{\circ} \mathrm{C}$ in July and absolute temperatures ranging from 45 to $-12{ }^{\circ} \mathrm{C}$. Air temperature was monitored at 10 -min intervals with an automatic HOBO data logger (Pro v2, ONSET, MA, USA) installed in a gap at the centre of the site.

Plants from three age-height classes [C1: seedlings $<20 \mathrm{~cm}$ high, 2-year-old seedlings; C2: seedlings between 21 and $50 \mathrm{~cm}$ high, 4- to 8-year-old seedlings; $\mathrm{C} 3$ : saplings between 51 and $200 \mathrm{~cm}$ high, more than 9 years old] were chosen for the study. The type of leaves on the seedlings differed according to the plant class due to the notable heteroblastic change that takes place between juvenile and adult vegetative phases in this species. Class $\mathrm{C} 1$ were 2-year-old seedlings comprising a juvenile shoot with solely primary needles, class $\mathrm{C} 2$ were seedlings in a transitional vegetative state (seedlings bore some secondary needles but retained abundant primary needles) and class $\mathrm{C} 3$ were seedlings that had an adult shoot with only secondary needles bundled in fascicles.

On nine dates between June 2009 and May 2010, LT tolerance in $P$. pinea recruitment was assessed. Primary needles were sampled for plants in classes $\mathrm{C} 1$ and $\mathrm{C} 2$, and secondary needles were sampled for plants in class C3. Samples were collected at 4-week intervals from June to mid-December 2009 (the acclimation period being from
September to early December) and from March to May 2010. Samples were collected in the field from six plants per class, one sample for each temperature and each plant tested. From June to mid-December 2009, the samples consisted of current-year lateral branch tips; from March to May 2010, overwintered needles were used. In the case of 2-year-old seedlings, samples consisted of the main shoot. Samples were of sufficient size to provide the needles required for the freezing tests. The samples were rinsed with water, blotted with paper towels, stored in plastic bags and transported in an insulated box to the laboratory where they were immediately prepared for freezing.

On each measuring date, six to eight samples of ten needles per class were used to determine needle mass area (LMA), calculated as needle dry mass per needle area (grams per square centimetre). Projected needle area was determined by scanning and posterior application of Winfolia2002a software (Regent Instruments Inc. Switzerland), while dry mass was obtained after oven-drying the needles at $70{ }^{\circ} \mathrm{C}$ for $24 \mathrm{~h}$. For each measuring date, differences in LMA between classes were analyzed using ANOVA.

\subsection{Artificial freezing test}

Electrolyte leakage was used to assess LT tolerance of foliage. Needles of current-year branches from each seedling of each class were cut into $2.5-$ to $3.0-\mathrm{cm}$ segments and mixed to produce a uniform sample of needles. All freezing tests were performed on six replicates per class and temperature. Samples were prepared from 15 needles per replicate, discarding tip and basal portions. The 15 segments were inserted into each of six 70-mL glass test tubes per class and temperature, with the segment tips submerged in $1 \mathrm{~mL}$ of $\mathrm{dH}_{2} \mathrm{O}$. Samples were cooled in a computer-controlled test climatic chamber (CM 0/81, DYCOMETAL) that monitored the temperature. One replicate per class was held at $4{ }^{\circ} \mathrm{C}$ (control), and the remaining samples were cooled at a rate of $5{ }^{\circ} \mathrm{C} \mathrm{h}^{-1}$ to a series of four to six target temperatures ranging from -3 to $-12{ }^{\circ} \mathrm{C}$ before acclimation and between -5 and $-30{ }^{\circ} \mathrm{C}$ during acclimation, with a 60 -min hold at each temperature to allow equilibration. Minimum target temperatures varied between dates (Table 1). At the end of each equilibration period, replicates were removed from the freezer and transferred to $\mathrm{a}+4{ }^{\circ} \mathrm{C}$ refrigerator, where they were allowed to warm passively overnight. With passive warming, samples from lower temperatures warm more rapidly initially, but warming rates converge asymptotically as samples approach $0{ }^{\circ} \mathrm{C}$, so that rates are similar when cells reabsorb most water from extracellular ice (Strimbeck et al. 2008). Ions were extracted with $20 \mathrm{~mL}$ of demineralized water for $24 \mathrm{~h}$ at $21{ }^{\circ} \mathrm{C}$ to allow electrolyte leakage to equilibrate. Initial conductivity was measured with a conductivity meter (HI 2300 Microprocessor Conductivity Meter, Hanna Instruments) after 
Table 1 Target freezing temperatures tested in each sampling date. Tested temperatures were the same for each age class within each sampling date

\begin{tabular}{|c|c|c|c|c|c|c|c|c|c|c|c|c|c|c|c|c|c|c|}
\hline \multirow[t]{2}{*}{ Year } & \multirow[t]{2}{*}{ Month } & \multicolumn{17}{|c|}{ Temperatures tested } \\
\hline & & -3 & -4 & -5 & -6 & -7 & -8 & -9 & -10 & -11 & -12 & -15 & -16 & -19 & -20 & -24 & -25 & -30 \\
\hline \multirow[t]{6}{*}{2009} & June & $\mathrm{x}$ & & & $\mathrm{x}$ & & & $\mathrm{x}$ & & & $\mathrm{x}$ & & & & & & & \\
\hline & July & $\mathrm{x}$ & & & $\mathrm{x}$ & & & $\mathrm{x}$ & & & $\mathrm{x}$ & & & & & & & \\
\hline & September & $\mathrm{x}$ & & & $\mathrm{x}$ & & & $\mathrm{x}$ & & & $\mathrm{x}$ & & & & & & & \\
\hline & October & $\mathrm{x}$ & & & $\mathrm{x}$ & & & $\mathrm{x}$ & & & $\mathrm{x}$ & & & & & & & \\
\hline & November & $\mathrm{x}$ & & & & $\mathrm{x}$ & & & & $\mathrm{x}$ & & $\mathrm{x}$ & & $\mathrm{x}$ & & & & \\
\hline & December & & & $\mathrm{x}$ & & & & & $\mathrm{x}$ & & & $\mathrm{x}$ & & & $\mathrm{x}$ & & $\mathrm{x}$ & $\mathrm{x}$ \\
\hline \multirow[t]{3}{*}{2010} & March & & & $\mathrm{x}$ & & & & & $\mathrm{x}$ & & & $\mathrm{x}$ & & & $\mathrm{x}$ & & $\mathrm{x}$ & $\mathrm{x}$ \\
\hline & April & & $\mathrm{x}$ & & & & $\mathrm{x}$ & & & & $\mathrm{x}$ & & $\mathrm{x}$ & & $\mathrm{x}$ & $\mathrm{x}$ & & \\
\hline & May & & $\mathrm{x}$ & & & & $\mathrm{x}$ & & & & $\mathrm{x}$ & & $\mathrm{x}$ & & $\mathrm{x}$ & & & \\
\hline
\end{tabular}

shaking the test tubes for $15 \mathrm{~min}$ at $20^{\circ} \mathrm{C}$. Samples were ovenheated at $90^{\circ} \mathrm{C}$ for $2 \mathrm{~h}$ to heat-kill the needles, allowed to cool overnight (lowered to $20{ }^{\circ} \mathrm{C}$ ), and the final conductivity measured, after shaking again. In each measurement series, the conductivity was also measured in six test tubes with demineralized water only, as a blank. Relative electrolyte leakage (REL), the ratio of initial to final conductivity, corrected for the baseline conductivity of solution blanks, was used as an index of injury. Non-linear curves defining REL response to decreasing temperatures $(T)$ were independently fitted to the electrolyte data of each individual from each age class. The non-linear relationship was defined by a modification of the classical logistic model, selected from among those showing an asymptotic pattern (Ratkowsky 1990, p. 128):

$\mathrm{REL}_{T}=\frac{\mathrm{REL}_{\text {max }}}{1+e^{\left(b-c^{*} T\right)}}$

where $\mathrm{REL}_{\text {max }}$ was assumed to have a constant asymptotic value given by the maximum level of cold injury observed for the samples over the whole experiment, which was close to 0.85 , and $b$ and $c$ are parameters to be estimated via non-linear least squares estimation. The use of a fixed value of $\mathrm{REL}_{\text {max }}$ as a proxy for the maximum relative conductivity attained after slow freezing has been previously proposed (Climent et al. 2009) to avoid fitting inconsistencies derived from using minimum freezing temperatures that do not cause maximum lethal injuries. After fitting this non-linear model following least squares techniques, parameters $b$ and $c$ are estimated for each plant. Thus, we are able to determine the expected behaviour of the curve for non-tested temperatures. Given the properties of the logistic function, $\mathrm{LT}_{50}=b / c$ is the inflection point, which coincides with the temperature at which REL equals $\mathrm{REL}_{\max } / 2$ and thus represents the temperature at which $50 \%$ cell mortality occurs (Strimbeck and Schaberg 2009; Strimbeck et al. 2008). Previous studies comparing REL with visible injury symptoms indicate that $\mathrm{REL}<0.5 \mathrm{REL}_{\text {max }}$ are associated with reversible chlorosis, while REL $>0.5 \mathrm{REL}_{\max }$ indicates cell death followed by necrosis (Strimbeck et al. 2007). Thus, relative LT tolerance was based on the mean value of $\mathrm{REL}_{\max }$ obtained from the curve fit for each age class and plant, using a threshold value of $0.5 \mathrm{REL}_{\text {max }}$ to classify each age class as LT sensitive or insensitive. Together with $\mathrm{LT}_{50}$, we also analyzed the individual responses in terms of $\operatorname{REL}_{\left(T=-12{ }^{\circ} \mathrm{C}\right) \text {, defined as the relative electrolyte leakage mea- }}$ sured at the absolute minimum temperature observed under field conditions at the study site $\left(-12^{\circ} \mathrm{C}\right)$. This value can be considered a proxy of LT tolerance to the most adverse winter conditions, under a natural environment.

Differences between age classes in $\mathrm{LT}_{50}$ and $\operatorname{REL}_{\left(T=-12{ }^{\circ} \mathrm{C}\right)}$ were analyzed over the study period by means of a repeated measurements general linear mixed model, considering age class, data and date $\times$ age class as fixed effects and a withinsubject random plant effect. If overall significant differences in the analyzed parameters were observed, single-date ANOVAs were carried out to define the temporal pattern of variability in age class response.

The non-linear relationship between LT tolerance parameters $\mathrm{LT}_{50}$ and $\operatorname{REL}_{\left(T=-12{ }^{\circ} \mathrm{C}\right)}$ and needle mass area (LMA), as a proxy to needle sclerophylly, was evaluated by fitting general log-linear models, testing also the heterogeneity of intercepts and slopes between age classes. All the statistical analyses were carried out using the STAT module of SAS ${ }^{\circledR}$ package.

\subsection{Shoot growth}

During 2009 (from February to December) and 2010 (from February to October), elongation of the main shoot was monitored every month in a bigger sample (45 to 60 plants per class). During the elongation phase, the current length of the shoot was expressed by the relative growth with regard to final elongation, minus the length recorded the previous winter. Relative shoot growth was then related to the sum of degree days (dd) (a rectangular daily approximation to the double integral of the temperature curve above a threshold in a time 
Fig. 1 a Relative conductivity at $-12{ }^{\circ} \mathrm{C}\left(\mathrm{REL}_{\left(T=-12{ }^{\circ} \mathrm{C}\right)}\right)$ and inflection point of the temperature response curve $\left(\mathrm{LT}_{50}\right.$, degree Celsius) in needles from three plant classes of $P$. pinea, between June 2009 and May 2010. b

Minimum, maximum (thin lines) and 5-day mean (thick line) air temperature and precipitation at the plot. Values of $\operatorname{REL}_{\left(T=-12{ }^{\circ} \mathrm{C}\right)}$ and $\mathrm{LT}_{50}$ are means of ten seedlings per age class

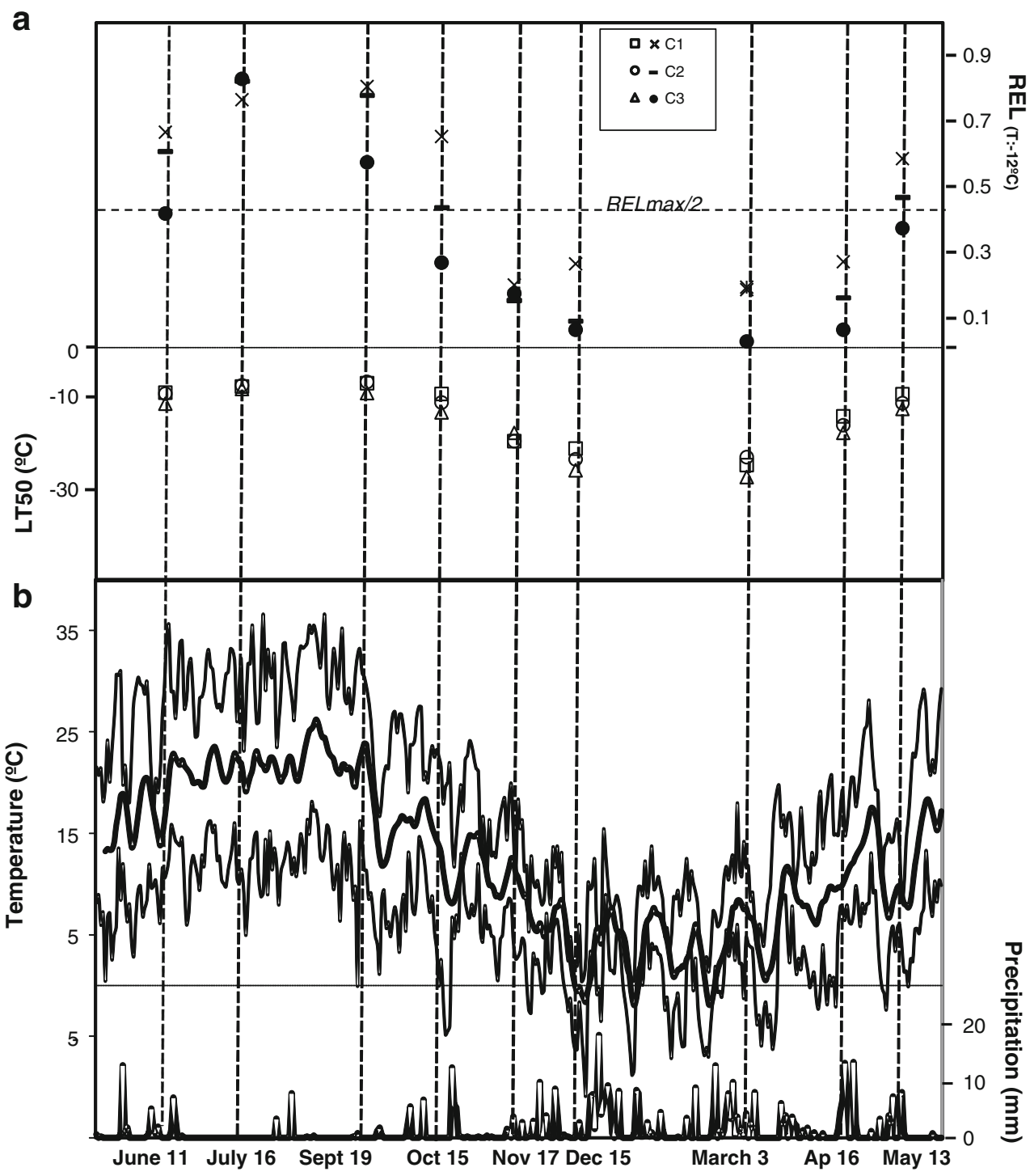

interval (see Mutke et al. (2003) for details) using a double exponential, which considers the left skewness in both time and thermal time scales for the growth pattern:

$G\left(\sum_{d_{0}}^{d} h u\right)=1-e^{-e^{-\left(\sum h u-b\right)}}$

where $G$ is the accumulative form of shoot growth, $\Sigma$ hu is the daily approximation to thermal integral from starting date $d_{0}$ to date $d, b$ is the moment of maximum growth and $c$ is the slope parameter. For stone pine stands in inland Spain, the conventional starting date $d_{0}$ for thermal integral computing in phenology studies is February 1. Class differences in shoot growth curve shape were evaluated by testing the homogeneity of parameters $b$ and $c$. To do this, parameters $b$ and $c$ in Eq. 2 were expanded including dummy class variables. Additionally, shoot growth data for a given plant can be considered a longitudinal series of repeated time observations, so random plot parameters were also included in the model, affecting

Table 2 Results of the general linear mixed model for repeated measured analysis for $\mathrm{LT}_{50}$ and $\mathrm{REL}_{\left(T=-12{ }^{\circ} \mathrm{C}\right)}$

\begin{tabular}{llllll}
\hline Effect & & $\mathrm{LT}_{50}$ & & \multicolumn{2}{l}{$\left.\mathrm{REL}_{(T=-12}{ }^{\circ} \mathrm{C}\right)$} \\
\hline \multirow{2}{*}{ Fixed } & Time & $P$ value & $F$ & $P$ value & $F$ \\
& $<0.0001$ & $1,351.30$ & $<0.0001$ & 632.96 \\
& Plant class & $<0.0001$ & 90.17 & $<0.0001$ & 84.96 \\
& Time $\times$ plant class & $<0.0001$ & 14.63 & $<0.0001$ & 15.98 \\
& & & & & \\
Random & Plant & 0.1733 & 0.94 & 0.2585 & 0.65 \\
Pairwise comparisons & $P$ value & & $P$ value & \\
C3-C1 & $<0.0001$ & & $<0.0001$ & \\
C3-C2 & $<0.0001$ & & $<0.0001$ & \\
C1-C2 & 0.0023 & & $<0.0001$ & \\
\hline
\end{tabular}


parameters $b$ and $c$. The final expression for shoot growth curve is given by

$$
G\left(\sum_{d_{0}}^{d} h u\right)=1-e^{-e^{-\left(\sum h u-\left(b+b_{2} D_{2}+b_{3} D_{3}+u\right)\right)}}
$$

where $D_{2}$ and $D_{3}$ are dummy variables, whose value equals 1 if the observation comes from classes $\mathrm{C} 2$ and $\mathrm{C} 3$, respectively, and 0 in the rest of cases, and $u$ and $v$ and are random plant parameters, distributed following a normal bivariate with mean zero and estimable variance-covariance matrix. Under this formulation, the shoot growth curve is given by estimated parameters $b+b_{2}$ and $c+c_{2}$ (class $\mathrm{C} 2$ ), $b+b_{3}$ and $c+c_{3}$ (class C3) and $b$ and $c$ (class C4). Data of each individual shoot growth were used to fit the shoot growth curve (Eq. 3) using the NLMIXED procedure in SAS ${ }^{\circledR}$. Modelling efficiency of the shoot growth curve EF was computed for each age class as $1-\mathrm{SSE} / \mathrm{CSS}$, where SSE is the error sum of squares and CSS is the corrected total sum of squares for the dependent variable.

\section{Results}

\subsection{Climatic conditions in the study site}

Following the trends of the previous 20 years, 2009 and 2010 had standard temperature conditions (Fig. 1). Daily thermal oscillation was $16-20{ }^{\circ} \mathrm{C}$ in the summer and $6-8{ }^{\circ} \mathrm{C}$ in late autumn-early winter (December 2009 and January 2010). Winter minimum temperatures fell to $-11{ }^{\circ} \mathrm{C}$. Five nights of frost were recorded in mid-October (Fig. 1). Daytime temperatures remained above freezing, with three nights of frost in late November. Maximum mean temperatures were positive all winter, although between December and March, night frosts were recorded on 15 days per month. During April (7 days) and May (4 days), sporadic night frosts of a few degrees below zero were recorded.

3.2 Low-temperature acclimation and relative conductivity: temperature response curves

The general linear mixed model for repeated measured analysis showed significant differences between sampling dates and plant classes in $\mathrm{LT}_{50}$ and $\left.\mathrm{REL}_{(T=-12}{ }^{\circ} \mathrm{C}\right)$ (Table 2). This means that the response of the samples to the controlled freezing test was largely dependent on the sampling date and on the plant class. Significant differences were identified between all three classes in both $\mathrm{LT}_{50}$ and $\left.\mathrm{REL}_{(T=-12}{ }^{\circ} \mathrm{C}\right)$ (Table 2). Overall, tolerance to freezing significantly increased (i.e. lower $\mathrm{LT}_{50}$ ) from class $\mathrm{C} 1$ (2-year-old seedlings, $\left.\mathrm{LS}_{\text {means }}=-14.192{ }^{\circ} \mathrm{C}\right)$, class $\mathrm{C} 2\left(\mathrm{LS}_{\text {means }}=-14.857^{\circ} \mathrm{C}\right)$ to class $\mathrm{C} 3$ (saplings, $\mathrm{LS}_{\text {means }}=-16.550{ }^{\circ} \mathrm{C}$ ). Accordingly, the index of freeze injury at $-12{ }^{\circ} \mathrm{C}\left(\operatorname{REL}_{\left(T=-12{ }^{\circ} \mathrm{C}\right)}\right)$ significantly decreased with plant age $\left(\mathrm{LS}_{\text {means_C1 }}=0.4846, \mathrm{LS}_{\text {means_C2}}=\right.$ $\left.0.4106, \mathrm{LS}_{\text {means } \mathrm{C} 3}=0.3087\right)$. The differences between plant classes for LT50 and $\operatorname{REL}_{\left(T=-12{ }^{\circ} \mathrm{C}\right)}$ in each sampling date are shown in Fig. 2.

$\mathrm{LT}_{50}$ values over the studied period ranged from -7.4 to $-27.9^{\circ} \mathrm{C}$. Values for $\mathrm{LT}_{50}$ were between -7.5 and $-9.8^{\circ} \mathrm{C}$ until mid-September. More rapid hardening occurred in midNovember following a cold period with several night frosts in mid-October. From mid-autumn, injury at the minimum test temperature affected all age classes, $\mathrm{LT}_{50}$ decreasing to between -18 and $-20{ }^{\circ} \mathrm{C}$ by mid-November. $\mathrm{LT}_{50}$ values were lowest at the end of winter $\left(-25^{\circ} \mathrm{C}\right.$ to $\left.-27.8^{\circ} \mathrm{C}\right)$, resulting from a previous 20 -day cold period with minimum temperatures below zero. $\mathrm{LT}_{50}$ approached their summer values by late May. By April 16, all classes had lost hardiness, concurrent with high mean temperatures $\left(11.4^{\circ} \mathrm{C}\right)$ and a decrease in the tolerance to freezing (Fig. 1). $\mathrm{REL}_{\left(T=-12{ }^{\circ} \mathrm{C}\right)}$ values confirmed that between late October and late April, plants were acclimated to temperatures as low as $-12{ }^{\circ} \mathrm{C}$, which is the absolute minimum temperature observed under field conditions at the study site (Fig. 1). Saplings (class C3) acclimated earlier in the autumn and deacclimated later in spring than seedlings.

Patterns of acclimation corresponded to those of a temperate species, revealing different styles of acclimation between classes (Fig. 3). Acclimation resulted in a shift in $\mathrm{LT}_{50}$ to a lower temperature until the end of the winter, while $\mathrm{LT}_{50}$ increased in early spring. The shift in $\mathrm{LT}_{50}$ to lower temperatures was more marked in saplings than in seedlings.

\subsection{LMA and relationship with LT tolerance parameters}

During the measuring period (June 2009 to May 2010), LMA showed a similar seasonal fluctuation for all classes, i.e. lower values in summer and higher values in winter (Fig. 4). As expected, secondary needles of $P$. pinea saplings (class C3) showed significantly higher LMA than primary needles of seedlings (classes $\mathrm{C} 1$ and $\mathrm{C} 2$ ) over the course of the year, except during the summer months.

As regards the relationship between LMA and LT tolerance parameters (Table 3, Fig. 5), we found significant non-linear relationships between $\mathrm{LT}_{50}$ and LMA $(P<0.0001)$ and between $\operatorname{REL}_{\left(T=-12{ }^{\circ} \mathrm{C}\right)}$ and LMA $(P<0.0001)$, fitted by means of a log-linear model. Both relationships point to a higher LT tolerance associated with larger LMA values. Tests of homogeneity of intercepts and slopes revealed no significant differences between plant classes for either $\mathrm{LT}_{50}$ vs LMA or $\operatorname{REL}_{\left(T=-12^{\circ} \mathrm{C}\right)}$ vs LMA relationships (Table 3). 
Fig. 2 Comparison of $\mathbf{a t T}_{50}$ and b $\operatorname{REL}_{\left(T=-12{ }^{\circ} \mathrm{C}\right)}$ between the three $P$. pinea plant classes during the sampling period. Intervals are standard errors, and means sharing the same letter are not significantly different after a Tukey's multiple range test $(P>0.05), n=6$ per age class and sampling date
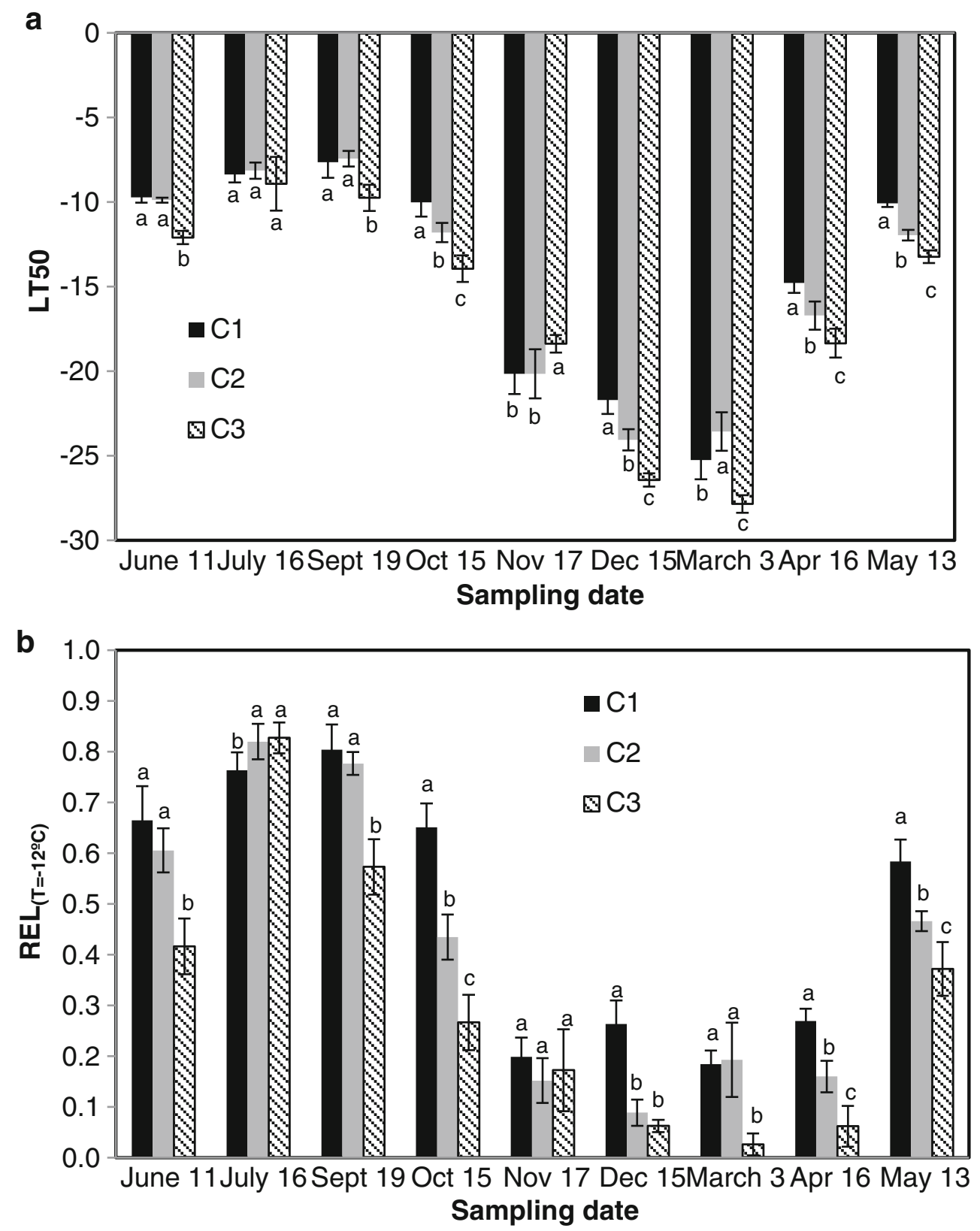

\subsection{Shoot growth phenology}

Shoot growth during 2009 and 2010, expressed in thermal time, exhibited a slow rate during early spring and a maximum close to the end of the elongation period (Fig. 6). In comparison to 2010, shoot growth in the spring of 2009 was 15 days ahead. Plants displayed different shoot growth curves according to the class. The non-linear mixed model revealed significant differences between seedlings in class $\mathrm{C} 1$ and class $\mathrm{C} 3$ for parameters $b(P<0.0001)$ and $c(P=0.0425)$, while no significant differences were shown between plants in classes $\mathrm{C} 2$ and $\mathrm{C} 3$. Classes $\mathrm{C} 1$ and $\mathrm{C} 2$ significantly differed in parameter $b(P<0.0001)$ but not in parameter $c$. Growth (see all parameters in Table 4) was always advanced in the youngest seedlings (class C1) and delayed in saplings (class C3). The moment of maximum growth (parameter $b$ ) was recorded between 1,395 degree days in class C1 seedlings (June 12, 2009 and June 22, 2010) and 1,606 degree days in class C3 saplings (June 21, 2009 and July 1, 2010). By the last night frost in 2010 (May 16), only the youngest seedlings had resumed growth.

\section{Discussion}

In this study we provide experimental evidence of the differences, linked to early developmental changes, in frost tolerance between age classes of Mediterranean $P$. pinea natural 

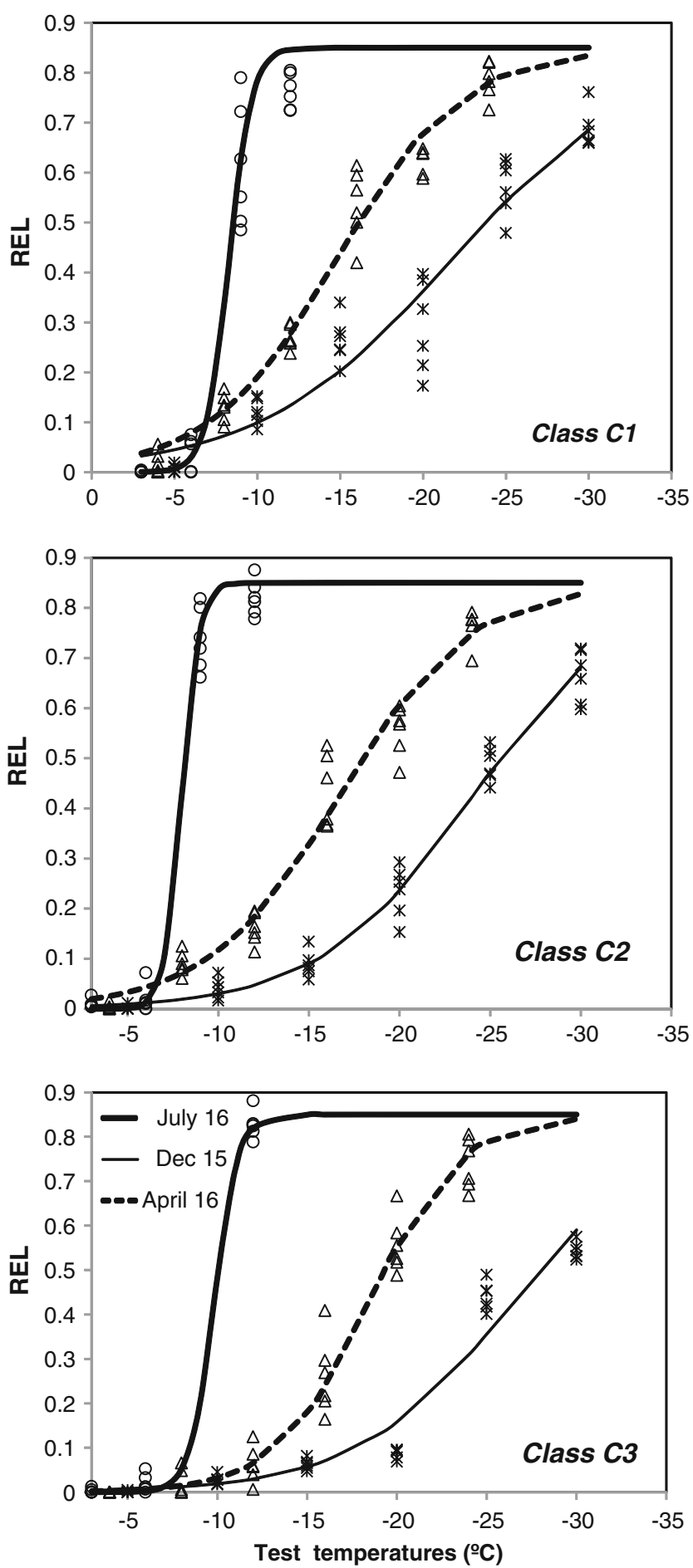

Fig. 3 Temperature vs relative electrolyte leakage (REL) before acclimation (July 2009), after acclimation (December 2009) and during deacclimation (April 2010), for the three P. pinea plant classes. Non-linear curves are fitted to the data from six plants for each plant class on each date. Data for each plant class and date is also shown

regeneration growing under highly continental conditions. Without exploring the different physiological capacities of LT acclimation (i.e. carbohydrates, antifreeze proteins, membrane characteristics) and considering the limitations of the

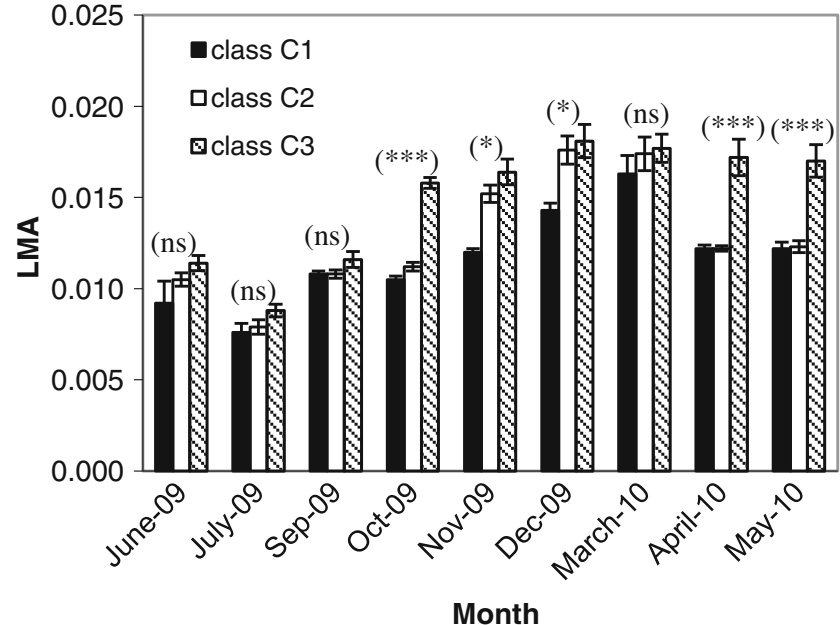

Fig. 4 Comparison of needle mass per area (LMA, grams per square centimetre) between age classes $(n=6-8$ samples per age class, ${ }^{* * *} P<0.001,{ }^{* *} P<0.01,{ }^{*} P<0.05$, ns non-significant)

post-freezing electrolyte leakage method to achieve $100 \%$ injury in pine needles (due to the high level of sclerophylly of the needles) as well as the difficulty involved in such trait sampling under natural conditions due to the different life spans of natural regeneration, our experiment confirmed that plant age class had an influence on LT tolerance, with saplings being the most tolerant to frosts. Furthermore, the differences encountered among classes were highly related to shoot ontogenetic heteroblasty, whereas the late frosts recorded during the studied period did not have a clear influence on shoot growth rate.

We have discussed LT tolerance through changes in $\mathrm{LT}_{50}$ and $\operatorname{REL}_{\left(T=-12{ }^{\circ} \mathrm{C}\right)} \cdot \mathrm{LT}_{50}$ is defined as the $50 \%$ injury point, for an observed maximum level of cold injury of 0.85 REL $_{\left(T=-12{ }^{\circ} \mathrm{C}\right)}$ is the relative electrolyte leakage measured at the absolute minimum temperature observed under field conditions at the study site $\left(-12^{\circ} \mathrm{C}\right)$. This value can be considered a proxy of LT

Table 3 Level of significance and test of homogeneity of slopes for log-linear models to predict LT tolerance parameters $\left(\mathrm{LT}_{50}\right.$ and $\left.\operatorname{REL}_{\left(T=-12{ }^{\circ} \mathrm{C}\right)}\right)$, using LMA as explanatory covariate and plant class as factor. Significant $P$ values are shown in italics

\begin{tabular}{lllll}
\hline & $\mathrm{LT}_{50}$ & & \multicolumn{3}{l}{$\left.\mathrm{REL}_{(T=-12}{ }^{\circ} \mathrm{C}\right)$} \\
\hline Source & $P$ value & $F$ & $P$ value & $F$ \\
LMA & $<0.0001$ & 66.59 & $<0.0001$ & 37.29 \\
Plant class & 0.8057 & 0.22 & 0.5984 & 0.53 \\
LMA $\times$ plant class & 0.5460 & 0.62 & 0.5650 & 0.59 \\
Test for homogeneity of slopes & $P$ value & & $P$ value & \\
C1-C2 & 0.6292 & & 0.7759 & \\
C2-C3 & 0.5032 & & 0.4279 & \\
C1-C3 & 0.2881 & & 0.3305 & \\
\hline
\end{tabular}



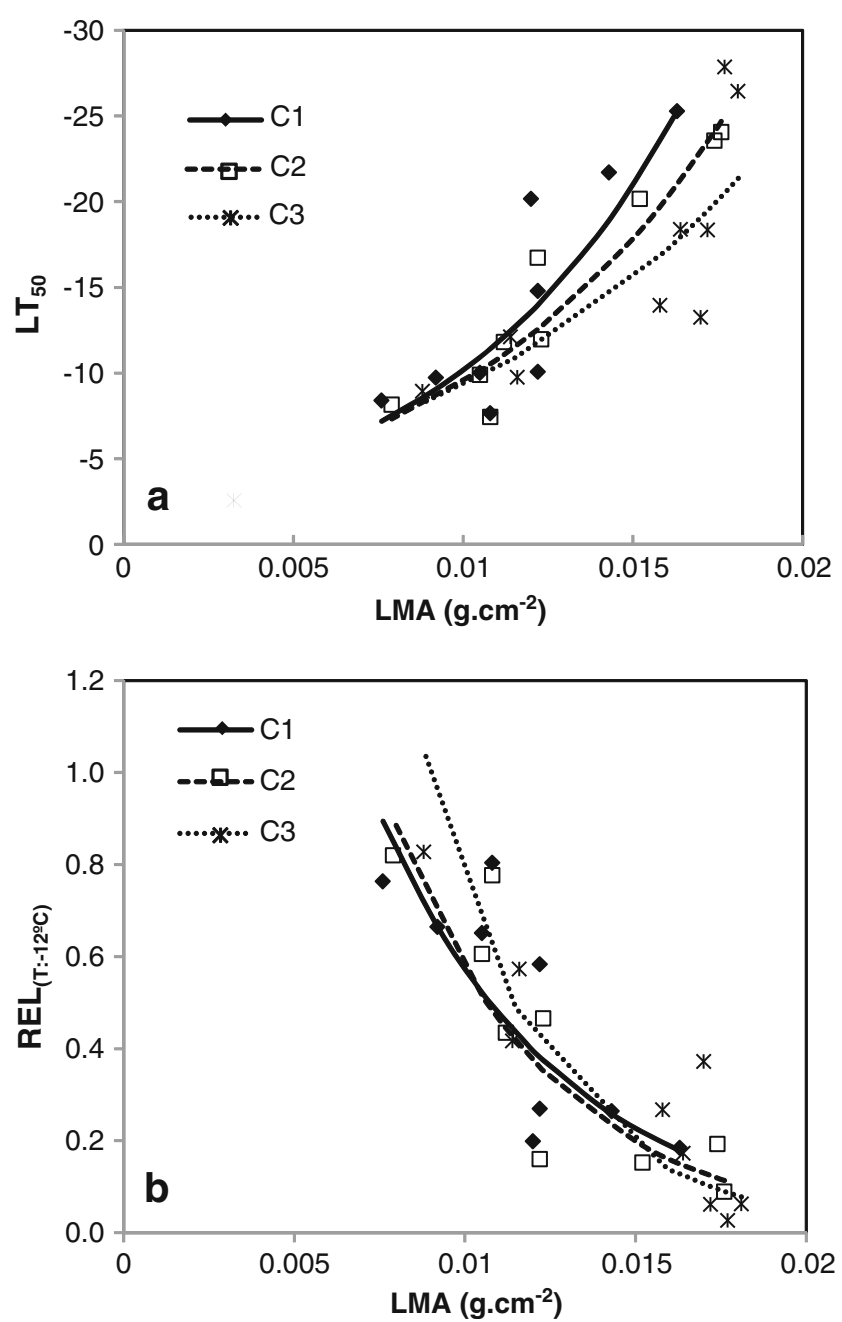

Fig. 5 Relationship between needle mass per area ( $L M A$, grams per square centimetre). a Inflection point of the temperature response curve ( $L T_{50}$, degree Celsius). b Relative conductivity at $-12{ }^{\circ} \mathrm{C}\left(R E L_{\left(T=-12{ }^{\circ} \mathrm{C}\right)}\right)$ in needles from the three plant classes sampled between June 2009 and May 2010. Each point represents the mean for each measuring date and age class. Each line represents the antilogarithmic transformation of the fitted $\log$-linear model $\log (y)=a+b \cdot$ LMA for each age class. See Table 3 for significance and tests of homogeneity of intercept slopes

tolerance to the most adverse winter conditions in a natural environment.

\subsection{Seasonal patterns of LT tolerance and LT acclimation of seedlings and saplings}

In the three plant classes, $\mathrm{LT}_{50}$ responded similarly to temperature, remaining stable or increasing slightly during periods of mild weather and decreasing during hardening (Fig. 1). The decrease in $\mathrm{LT}_{50}$ between September 19 and October 15 marked the beginning of the acclimation process for all plant classes. However, saplings (class C3) acclimated more rapidly than seedlings (classes $\mathrm{C} 1$ and $\mathrm{C} 2$ ), becoming tolerant to temperatures of at least $-12{ }^{\circ} \mathrm{C}$ by October. Numerous studies have shown that acclimation is not immediate, as frost hardiness does not respond immediately to short-term changes in the environment but rather according to a time constant. Thus, it is more related to day length (shorter days) than to climate (e.g. Bigras et al. 2001). According to previous studies involving conifers (Lindgren and Nilsson 1992; Repo et al. 2000; Strimbeck et al. 2008), acclimation is related to the latitude and usual date of occurrence of the first freezing temperatures in the regions of origin.

$\left.\operatorname{REL}_{(T=-12}{ }^{\circ} \mathrm{C}\right)$ remained high during summer until September 19 , indicating $100 \%$ cell mortality of needles after slow freezing, prior to acclimation. By October 15, sampled needles of seedlings from classes $\mathrm{C} 1$ and $\mathrm{C} 2$ were mortally injured when submitted to a temperature of $-12{ }^{\circ} \mathrm{C}$, while saplings (class C3) exhibited acclimation to that temperature. All seedlings were acclimated to a temperature of $-12{ }^{\circ} \mathrm{C}$ between October 15 and April 16, while saplings still showed LT tolerance to $-12{ }^{\circ} \mathrm{C}$ by May $3 . \mathrm{LT}_{50}$ decreased to a range between -18 and $-20{ }^{\circ} \mathrm{C}$ in mid-November and to -24 and $-27{ }^{\circ} \mathrm{C}$ in early March, with the saplings (class $\mathrm{C} 3$ ) again showing a higher LT tolerance. The decrease in $\mathrm{LT}_{50}$ in November for all classes (Fig. 1) occurred after the first frosts of the year in late October. It seems that night frosts increase LT tolerance in stone pine, as postulated for other temperate species (Silim and Lavender 1994; Strimbeck and Schaberg 2009). By late winter, frost hardiness was lost, resulting in decreasing LT tolerance (Thomas and Sporns 2009).

Deacclimation in the three stone pine classes had already begun by April, although below zero night temperatures were still recorded on 7 days at the beginning of April and on 4 days until mid-May. The negative effect of late spring frosts on stone pine can change every year, depending on the moment at which shoot growth resumes. It seems that LT hardening and the timing of growth onset are synchronized with seasonal changes in temperature through an array of combinations of environmental factors (Sogaard et al. 2009). As stone pine shoot growth is temperature dependent, the growth function expressed over thermal time (sum of degree days) can be fitted for the weather conditions in each year (Fig. 6) (Mutke et al. 2003). According to this function, stone pine shoot growth resumed at different moments in each of the two studied years and was dependent on the age class, arriving earlier in the youngest seedlings. Since shoot elongation is based on the expansion of preformed structures, the date when the maximum growth is reached will be dependent on thermal time; thus, shoot phenology can be several weeks ahead (10 days difference between 2009 and 2010). Such advances in shoot phenology could be very negative if sporadic night frosts in May-June (when shoots are actively growing) occur, this being a common occurrence in stone pine stands in central Spain (Mutke et al. 2012). Interestingly, in our study, late frosts did not have a clear influence on shoot growth rate and did not produce any visible damage to shoots. This can be explained by the fact that in spring 2010, the last night frost 
Fig 6 Predicted relative shoot growth in degree-day scale $[d d]$ and the corresponding date in 2009 and 2010, for seedlings of the three age classes. Circles represent days when the freeze test was done

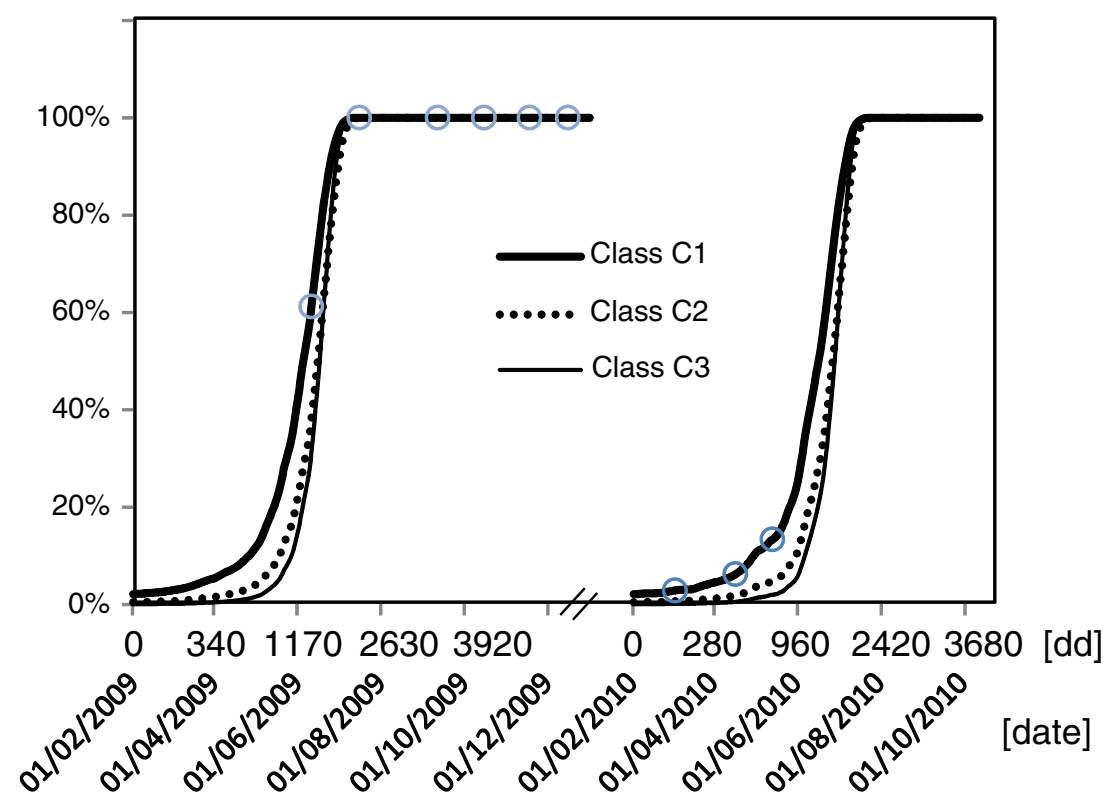

occurred when plants were not still actively growing (plants from class $\mathrm{C} 1$ had reached only $10 \%$ of total shoot growth, and plants from classes $\mathrm{C} 2$ and $\mathrm{C} 3$ had just resumed growth).

\subsection{Differences between classes: ecological implications}

Previous studies have discussed seasonal variations in leaf traits (e.g. Ma et al. 2011). Leaf traits are driven by internal constraints of leaf and whole plant (Westoby et al. 2002), and they respond to climatic fluctuations much more slowly. Leaf mass per unit area (LMA) was higher in saplings (which bear mature needles) than in seedlings (with mostly juvenile needles). This is consistent with results for other species and probably reflects continuous accumulation and lignification of cell wall materials during needle aging (Han et al. 2008).

Our results showed that saplings were significantly more tolerant to freezing injury than young seedlings, which supports previous findings (e.g. Kreyling et al. 2013) and is in consonance with a well-established ontogenetic trend in trees (Bannister and Neuner 2001). The differences in LT tolerance between classes were closely linked to the observed differences in foliage type (primary vs secondary needles), which in

Table 4 Average growth parameters in the monitored shoots of 45-60 plants per age class, during 2009 and 2010. $b$ moment of maximal growth rate; $c$ slope parameter; $T_{0.1}, T_{0.5}, T_{0.9}$ sum of degree days (dd) with 10,50 turn related significantly to differences in their leaf mass per area (Table 3, Figs. 4 and 5). In a previous greenhouse experiment with 18-month-old stone pine seedlings, primary and secondary needles collected from the same individuals were reported to behave similarly in $\mathrm{LT}_{50}$ (Climent et al. 2009). This similarity in frost tolerance is probably found in the transitional developmental state, that is, when seedlings bear both primary and secondary needles, but not when comparing secondary needles of saplings with primary needles of younger seedlings. It is worthy of note that secondary needles showed a higher resistance to water loss than primary needles, even at the transitional stage (Pardos et al. 2009). Thus, our results support the postulation that in the case of stone pine, delayed heteroblastic change may have been favoured by natural selection to enable the construction of droughtresistance foliage (Climent et al. 2011) which is also cold resistant (positive relationship between $\mathrm{LT}_{50}$ and LMA and between $\operatorname{REL}_{\left(T=-12{ }^{\circ} \mathrm{C}\right)}$ and LMA).

Late spring frosts during the studied period did not have a clear influence on shoot growth rate. However, the predicted increase in mean temperature for the Iberian Peninsula could lead to significant phenological changes (Mutke et al. 2003),

and $90 \%$ of total growth, respectively. Dates when $T_{0.1}, T_{0.5}$ and $T_{0.9}$ were achieved are shown separately for 2009 and 2010

\begin{tabular}{|c|c|c|c|c|c|c|c|c|c|c|c|}
\hline & \multicolumn{2}{|c|}{ Parameters of the curve } & \multicolumn{3}{|c|}{ Sum of degree days (dd) } & \multicolumn{3}{|l|}{2009} & \multicolumn{3}{|l|}{2010} \\
\hline & $b$ & $c$ & $T_{0.1}$ & $T_{0.5}$ & $T_{0.9}$ & Date_$T_{0.1}$ & Date_ $T_{0.5}$ & Date_$T_{0.9}$ & Date_ $T_{0.1}$ & Date_ $T_{0.5}$ & Date_$T_{0.9}$ \\
\hline Class C1 & 1,395 & -364 & 587 & 1,264 & 1,703 & April 27 & June 5 & June 25 & April 30 & June 16 & July 5 \\
\hline Class C2 & 1,597 & -303 & 933 & 1,484 & 1,843 & May 19 & June 15 & July 1 & May 31 & June 26 & July 10 \\
\hline Class C3 & 1,605 & -235 & 1,083 & 1,531 & 1,814 & May 28 & June 17 & June 29 & June 6 & June 28 & July 9 \\
\hline
\end{tabular}


such that advanced phenology in stone pine may increase the risk of late-frost injury to growing tissues. Thus, although global warming is unlikely to cause the disappearance of sporadic late spring frost events, the advanced onset of growth associated with this warmer world could result in more frost damage due to the lack of acclimation and plant synchrony with the environment. The correlations between the shoot ontogenic changes occurring during the early stages and the effects of phenological shifts in Mediterranean stone pine driven by warmer winters should be investigated in a longerterm experiment to further our understanding of LT acclimation and adaptation in this species under future climate change scenarios. Another important issue for further investigation is the adaptive advantage associated with delayed heteroblasty in stone pine.

Acknowledgement We are grateful to the Forest Services of the Junta de Castilla y León (in particular to Ayuntamiento de Portillo) for permission to conduct the field experiment. Thanks to R. Chambel and to the colleagues and technicians who helped us in the lab.

Funding This research was supported by INIA projects RTA200700044 and AT2010-007, national project AGL2010-15521 and regional project S2009-AMB1668.

\section{References}

Bannister P, Neuner G (2001) Frost resistance and the distribution of conifers. In: Bigras FJ, Colombo SJ (eds) Conifer cold hardiness. Kluwer, Dordrecht, pp 3-21

Bigras FJ, Ryyppö A, Lindström A, Stattin E (2001) Cold acclimation and deacclimation of shoots and roots of conifer seedlings. In: Bigras FJ, Colombo SJ (eds) Conifer cold hardiness. Kluwer, Dordrecht, pp 57-88

Bower AD, Aitken SN (2006) Geographic and seasonal variation in cold hardiness of whitebark pine. Can J For Res 36:1842-1850

Burr KE, Tinus RW, Wallner SJ, King RM (1990) Comparison of three cold hardiness tests for conifer seedlings. Tree Physiol 6:351-369

Calama R, Mutke S, Gordo JM, Montero G (2008) An empirical ecological-type model for predicting stone pine (Pinus pinea L.) cone production in the Northern Plateau (Spain). For Ecol Manag 255 (3/4):660-673

Calama R, Mutke S, Tomé JA, Gordo FJ, Montero G, Tomé M (2011) Modelling spatial and temporal variability in a zero-inflated variable: the case of stone pine (Pinus pinea L.) cone production. Ecol Model 222:606-618

Castro-Díez P, Montserrat-Martí G (1998) Phenological patterns of fifteen Mediterranean phanaerophytes from Quercus ilex communities of NE-Spain. Pl Ecol 139:103-112

Climent J, Costa e Silva F, Chambel MR, Pardos M, Almeida MH (2009) Freezing injury in primary and secondary needles of Mediterranean pine species of contrasting ecological niches. Ann For Sci 66:407

Climent J, San-Martín R, Chambel MR, Mutke S (2011) Ontogenetic differentiation between Mediterranean and Eurasian pines (sect. Pinus) at the seedling stage. Trees 25:175-186

Costa e Silva F, Shvaleva A, Broetto F, Ortuño MF, Rodrigues ML, Almeida MH, Chaves MM, Pereira JS (2009) Acclimation to short-term low temperatures in two Eucalyptus globulus clones with contrasting drought resistance. Tree Physiol 29:77-86
Darrow HE, Bannister P, Burritt DJ, Jameson PE (2001) The frost resistance of juvenile and adult forms of some heteroblastic New Zealand plants. N Z J Bot 39:355-363

Ensminger I, Hüner NPA, Busch F (2009) Conifer cold hardiness, climate change and the likely effects of warmer temperatures on photosynthesis. In: L.V. Gusta, M.E. Wisniewski \& K.K. Tanino (eds). Plant cold hardiness. From the laboratory to the field . CAB International, pp. 249-261

Gusta LV, Wisniewski ME, Trischuk RG (2009) Patterns of freezing in plants: the influence of species, environment and experimental procedures. In: L.V. Gusta, M.E. Wisniewski \& K.K. Tanino (eds). Plant cold hardiness. From the laboratory to the field. CAB International, pp. 214-225

Han Q, Kawasaki T, Nakano T, Chiba Y (2008) Leaf-age effects on seasonal variability in photosynthetic parameters and its relationships with leaf mass per area and leaf nitrogen concentration within a Pinus densiflora crown. Tree Physiol 28:551-558

Hannertz M (1994) Damages to Norway spruce (Picea abies L.) seedlings caused by a late spring frost. Skogfprst Rep. no. 5

Jones CS (1999) An essay on juvenility, phase change, and heteroblasty in seed plants. Int J Pl Sci, 160(6), S105-S111. Retrieved from $<$ Go to ISI $>: / / 000084853500008$

Kalcsits L, Silim S, Tanino K (2009) The influence of temperature on dormancy induction and plant survival in woody plants. In: L.V. Gusta, M.E. Wisniewski \& K.K. Tanino (eds). Plant cold hardiness. From the laboratory to the field. CAB International, pp 108-118

Klaus W (1989) Mediterranean pines and their history. Pl Syst Evol 162: $133-163$

Kreyling J, Wiesenberg GLB, Thiel D et al (2013) Cold hardiness of Pinus nigra Arnold as influenced by geographic origin, warming, and extreme summer drought. Environ Exp Bot 78: 99-108

Lanner RM (1976) Patterns of shoot development in Pinus and their relationship to growth potential. In: Cannell MGR, Last FT (eds) Tree physiology and yield improvement. Academic, London, pp 223-243

Larcher W (2005) Climatic constraints drive the evolution of low temperature resistance in woody plants. J Agric Meteorol 61: 189-202

Lindgren K, Nilsson JE (1992) Cold acclimation of Pinus sylvestris and Pinus contorta provenances as measured by freezing tolerance of detached needles. Scand J For Res 7:309-315

Ma S, Baldocchi DD, Mambelli S, Dawson TE (2011) Are temporal variations of leaf traits responsible for seasonal and inter-annual variability in ecosystem $\mathrm{CO}_{2}$ exchange? Funct Ecol 25:258-270

Manso R, Pardos M, Keyes C, Calama R (2012) Modelling the spatiotemporal pattern of primary dispersal in stone pine (Pinus pinea L.) stands in the Northern Plateau (Spain). Ecol Model 226:11-21

Manso R, Fortin M, Calama R, Pardos M (2013) Modelling seed germination in forest tree species through survival analysis. The Pinus pinea L. case study. For Ecol Manag 289:515-524

Manso R, Pukkala R, Pardos M, Miina J, Calama R (2014) A multistage stochastic regeneration model for Pinus pinea $\mathrm{L}$ in the Northern Plateau (Spain), Can J For Res. doi:10.1139/cjfr2013-0179

Mutke S, Gordo J, Climent J, Gil L (2003) Shoot growth and phenology modelling of grafted Stone pine (Pinus pinea L.) in Inner Spain. Ann For Sci 60:527-537

Mutke S, Gordo J, Gil L (2005) Variability of Mediterranean stone pine cone production: yield loss as a response to climate change. Agric For Meteor 132:263-272

Mutke S, Calama R, González-Martínez S, Montero G, Gordo J, Bono D, Gil L (2012). Mediterranean stone pine: botany and horticulture. In: Janick J. (ed.): Horticultural Reviews 39, 1st edn. Wiley-Blackwel, pp 153-201 
Palacio S, Milla R, Montserrat G (2005) A phenological hypothesis on the thermophilous distribution of Pistacia lentiscus L. Flora 200: $527-534$

Pardos M, Calama R, Climent J (2009) Difference in cuticular transpiration and sclerophylly in juvenile and adult pine needles relates to the species-specific rates of development. Trees 23:501-508

Pardos M, Puértolas J, Madrigal G, Garriga E, de Blas S, Calama R (2010) Seasonal changes in the physiological activity of regeneration under a natural light gradient in a Pinus pinea regular stand. For Syst 19:367-380

Puértolas J, Gil L, Pardos JA (2005) Effects of nitrogen fertilization and temperature on frost hardiness of Aleppo pine (Pinus halepensis Mill.) seedlings assessed by chlorophyll fluorescence. Forestry 78:501-511

Ratkowsky DA (1990) Handbook of nonlinear regression models. Marcel Dekker, New York, 241 pp

Repo T, Zhang G, Ryyppö A, Rikala R, Vuorinen M (2000) The relation between growth cessation and frost hardening in Scots pine of different origins. Trees 14:456-464

Sakai A (1983) Comparative study on freezing resistance of conifers with special reference to cold adaptation and its evolutive aspects. Can J Bot 61:2323-2332

Silim SN, Lavender DP (1994) Seasonal patterns and environmental regulation of frost hardiness in shoots of seedlings of Thuja plicata, Chamaecyparis nootkatensis and Picea glauca. Can J For Bot 72: 309-316
Sogaard G, Granhus A, Johnsen O (2009) Effect of frost nights and day and night temperature during dormancy induction on frost hardiness, tolerance to cold storage and bud burst in seedlings of Norway spruce. Trees 23:1295-1307

Strimbeck GR, Schaberg PG (2009) Going to extremes: lowtemperature tolerance and acclimation in temperate and boreal conifers. In: Gusta L., Wisniewski $\mathrm{M}$ and Tanino K (eds.) Plant cold hardiness: from the laboratory to the field. CAB International, pp 227-239

Strimbeck GR, Kjellsen TD, Schaberg PG, Murakami PF (2007) Cold in the common garden: comparative low-temperature tolerance of boreal and temperate conifer foliage. Trees 21:557-567

Strimbeck GR, Kjellsen TD, Schaberg PG, Murakami PF (2008) Dynamics of low-temperature acclimation in temperate and boreal conifer foliage in a mild winter climate. Tree Physiol 28:1365-1374

Thomas F, Sporns K (2009) Frost sensitivity of Fagus sylvatica and co-occurring deciduous tree species at exposed sites. Flora 204:74-81

Westoby M, Falster DS, Moles AT, Vesk PA, Wright IJ (2002) Plant ecological strategies: some leading dimensions of variation between species. Ann Rev Ecol Syst 33:125-159

Winn AA (1999) The functional significance and fitness consequences of heterophylly. Int J Plant Sci 160:S113-S121

Zotz G, Wilhelm K, Becker A (2011) Heteroblasty-a review. Bot Rev 77:109-151 